\title{
ECONOMIC POSITIVISM AS RHETORIC
}

I characterized my project in the Alliance of Iron and Wheat as "constitutional history" in the broadest sense, for the question I had posed was "how and why the Third Republic was refounded as a conservative state at a time of the founding of other new conservative polities in Europe" (p.7). My strategy was two-fold. First, drawing from the theoretical assessment of late nineteenth-century German state-consolidation of Hans Rosenberg and the Bielefeld school, I found that important qualities that made up the paradigm of the Sonderweg could be identified in the beginnings of the Third French Republic. Thus I agreed with Geoff Eley and David Blackbourn that Germany was not so unique; indeed, I implicitly endorsed Alexander Gerschenkron's suggestion that perhaps Germany might be a more useful model for the study of development than Britain. France in the late nineteenth century was more like Germany than national(ist) historians perhaps realized; I was attempting to write a more comparative kind of European history. ${ }^{*}$

Second, within the specificity of the history of the Third Republic I suggested that the Great Depression of 1873-1896, coming at a decisive turning point in French politics, created the possibilities for the formation of a new grand ruling coalition in the new republic. Taking an old and tried weapon of French commercial policy (after the freetrade hiatus under Napoleon III) certain industrialists and growers - past and still potential economic and political antagonists - both pressed their political representatives for elevated tariffs as a solution to problems, now in the new republic, understood by them as common concerns: these were, of course, depressed prices, threatened markets, and foreign competitors. But, I argued, although these appeals for new tariffs were calls, to be sure, for old wine in old bottles, the protectionist industrialists and growers, deeply aware of the Social Question in the new age of industrial capitalism, advocated that the brew be fortified with newly-distilled additional spirits. For tariffs would also - French industrialists and their political friends and relatives argued - permit better control of costs, chief of which they understood to be the cost of their labor force. The alliances forged in these

* I want here to thank my friends Michael Hanagan, Eric Lampard, Barbara Weinstein, and Andrés Reggiani for offering me their helpful thoughts in the course of my writing this essay. Certainly, they have no responsibility for my final arguments, and might even demur from some of them. 
economic struggles for the tariffs laid the basis in trust for the more difficult task of forging a governing coalition. Most of my book then goes on to treat the fascinating story of the unfolding of this new governing alliance. I examined the attempts of conservatives to win the loyalty of the rural agricultural population in the new state. I connected the story of the Ralliement to my account of tariff coalitions. I assessed the role of colonies not primarily as potential countercyclical forces, nor just places of missionary work, but above all as the occasion for reconciliation of conflicts originating in the metropole, as an aid to state-building back home. And finally, in the last chapter I investigated the duel between Jules Méline and Jean Jaurès in the years of the Méline ministry over the loyalty of the "rural democracy". My conclusion was that the alliance of iron, cotton, and wheat lasted. "What the Opportunist republicans created persisted for the existence of the Third Republic and - it can be argued - into the early postwar years" (p.192).

This way of situating my work, I think makes manifest both the agreement (which is significant) and the disagreement between Michael Smith and myself on how to understand the creation of social stability in the new French republic. ${ }^{1}$ Curiously, despite his rejection of the reductionism of surplus value calculations, Smith seems here the economic determinist who wants just the facts, the numbers. He dismisses policy statements by dominant figures in French politics, business, and agriculture as "rhetoric", "a smokescreen". Nor does he even inquire into the dominant common sense of the day, the doxa, to employ Pierre Bourdieu's term, about how the economy functioned, the economic hopes, worries, guesses, fantasies, and miscalculations of historical actors. With the facts and the numbers plus a bit of economics of the firm and international trade theory - Smith proposes to see behind protectionists' verbal tricks to get at their "true goals". Accordingly, in his article he defines two questions. First, he poses for himself the narrow economistic query, "Was the Méline tariff intended primarily to pacify labor?" I say "puts for himself", because this was not my question, nor is it the way I formulate my discussion; it is a reductionist reading of the issues and of my text. Then he asks, did the tariffs cool the economic radicalism of workers? The methodological strategy here is to

${ }^{1}$ In confirmation of what I will argue below, Smith may not be the best reader of his own work. There are no social issues discussed in the body of his book. In his Introduction (pp. 23-25), and the Conclusion (pp. 239-254) he makes general unsupported statements about the constellations of social forces in the Third Republic. "Peasants", "workers", and "strikes" do not merit entries in his Index. It goes beyond the evidence he presented in his Tariff Reform in France for him now to claim that he too "portrayed" the conservative alliance of industrialists, big landowners, and peasant farmers as attempting "to defend the Third Republic against the attacks of the disaffected, notably the rising industrial working class". 
read back from empirical results to motives of actors - both workers and their employers.

Smith's argument, it seems to me, requires two kinds of answers. First let me respond in the arena of economic dispute as he frames it, so as not to be evasive. Then, more importantly, I want to critique Smith's posing of the questions and modes of responding to them. Smith focuses his criticism on two issues: the adequacy of evidence upon which a piece of my argument rests and the choice of economic paradigm to evaluate the evidence. $\mathrm{He}$ then offers a technological-upgrade argument to counter my social conflict model. In the beginning of his article he proposes that "we agree on what the protectionists were saying, but we disagree on their motives and intentions", and at the end he denounces the narrow labor-obsession of "the Marxist".

On the issue of evidence linking trade protectionism and workers remuneration Smith wants to put my feet to the fire with a principle of verification - a demand for "hard evidence" which would make many a physicist fear for the life of his theories. He wants "a scenario that would perfectly and unambiguously verify"; he demands "compelling evidence". Since he rules out of court the claims by important industrialists, leaders of their associations, and powerful politicians that tariff policy was social policy, we are asked to fish in dusty local and company archives where capitalists presumably wrote down what their genuine motives were and where true business data would allow us to test the real financial condition of their business.

Let me speak first to the issue of measuring workers' income. When researching The Alliance of Iron and Wheat my best information suggested that real wages did rise in French industry in the years after the passage of the Méline tariff. Smith admits this to have been the case in the years 1896-1907 (n. 41), although we would agree that, for the decades before World War I, both information on the cost of living and on nominal wages, and inferences from the data, are not very reliable. In assessing the return to workers we must add the further complication, as Michael Hanagan has recently argued, that in the Third Republic, particularly in heavy industry, French industrialists increased paternalist measures. Paternalism equals higher real wages plus greater control over workers. Noting that Smith underlines the importance of the adhesion of heavy metalworking industrialists to the success of the Méline coalition, Hanagan points out that "protectionism made it possible for them to increase and expand the paternalist traditions they had begun". ${ }^{2}$ Moreover, Eric Lampard suggests

${ }^{2}$ Letter of Michael Hanagan to the author, 10 February 1991. See further Hanagan and Miriam Cohen, "Welfare Capitalism and Heavy Industry: Birmingham, Pittsburgh, and Saint-Etienne, 1900-1930", paper presented to the annual meeting of the American Historical Association, Chicago, December 1991. 
that tariffs may well have dampened industrial conflict by permitting industrialists to avoid the pay cuts lowered prices would have put on their agendas. $^{3}$

Methodologically the issue here is what shall we take as evidence that tariffs legislation, among other things, qua labor pacifying policy worked or failed? The frequency of strikes after 1892? Unemployment data? The crime rate? Real wages in selected protected and unprotected industries? The founding of the CGT and SFIO? The second founding and the survival of the Third Republic? The non-occurrence of a social revolution in France? Smith has arbitrarily chosen a narrowly positivistic terrain to work; I think not much will grow there.

How much more evidence do we need today that neither economics nor theories of management are highly predictive sciences? If we judged the competence of businessmen, and economists, by how accurately their projections predicted the future, the vast majority both in the nineteenth century and now would fail what Donald McCloskey has called the "American Question': "If they're so smart, why aren't they rich?" Over a hundred years ago - with the finest calculations of their rational self-interest - how accurately could French business leaders and politicians have predicted the outcomes, or indeed brought about the outcomes, of their intended actions $?^{4}$ French protectionists worked to make the discourse of social protectionism the dominant one in society. That French workers could not gain serious welfare measures from their employers until the wave of strikes during another depression in the beginning of the Popular Front in 1936 suggests that their employers had largely succeeded.

This brings us to the second and more important issue: intentions, motivations. Since contemporary psychoanalysts have great difficulty understanding a person's motivation and throw up their hands at predicting behavior, and many psychologists do not even consider analyzing motivation a worthwhile scientific project, we should be suspicious of Smith's confident analysis of the real intentions of industrialist protectionists. What he calls "motives" turns out to be the old classic assumptions of economic man, some basic international trade theory, plus some guessing about

${ }^{3}$ Letter to the author by Eric Lampard, 1 March 1991.

${ }^{4}$ Donald N. McCloskey, in The Rhetoric of Economics (Madison, WI, 1985), p. 15 , endorses Ludwig von Mises's conclusion that foretelling the economic future is "beyond the power of any mortal man". He also reproduces the contents of a humorous memorandum - with an edge of healthy professional self-doubt - which staff at the office of the U.S. President's Council of Economic Advisors compiled in May 1983 containing such wonderful principles as the "Makiw's Maxim: No issue in economics has ever been decided on the basis of the facts.' 'Nihilistic Corollary I: No issue has ever been decided on the basis of theory either.' 'Frisch's Restatement: Never let the facts stand between you and the right answer.' 'McCaleb's Policy Prescription Principle: All policy implications drawn from economics are matters of faith' (p. 31).' 
reasons for certain indeterminate outcomes. ${ }^{5}$ What I tried to do in my study - and I am more convinced now that that is a good path for studies in the history of economics to take - was to try better to understand the world (which includes both their hopes and attempts at calculations) of the actors in the tariff story. Asking, as Smith does, whether the industrialist protectionists really believed tariff policy was social policy as Jules Méline, their friend asserted, is an invitation to dig for evidence defined in a way that will never satisfy the absolute definition of truth claims he proposes, to hunt for clues in a hopeless maze of true reasons and pretended ones. It is possible, as I tried to do, to approach an understanding of the mentalité of protectionists by looking at the elaboration of their discourses about the economic sphere.

The world protectionist language described looked something like this: The majority of the consumers of French manufactured goods in the first decades of the Third Republic, leaving aside luxury exports and sales to the colonial empire, was the rural population. The depression was cutting their incomes and purchasing power; they were less able to buy the industrial goods made by French industrialists employing French workers. Since it was the doxa of late nineteenth-century French business circles that economic crisis was a product of some mix of overproduction or underconsumption, industrialists' representatives in the Chamber, by helping their grower brethren and peasant producers via agrarian tariffs, pursued legislation which made good sense. ${ }^{6}$ If food prices rose as a consequence, at least the family firm, the patrimoine, was safe; their rural customers could buy their wares. In turn higher industrial tariffs would perhaps make agriculturalists pay higher prices for industrial goods, but National Labor would be safe.

Living and doing business in an economic world not yet peopled by marginalists, French protectionist industrialists and their chosen spokespeople (spokesmen, as it happens) subscribed to a labor theory of value. Accordingly, although they had to pay attention to many costs - interest rates, technological modernization, even differential railroad rates, to name some, their labor costs and labor peace - understood by them as imposed from above certainly - were central, if not exclusive, to their estimations of future business success. And their vision of the role of the

\footnotetext{
${ }^{5}$ Smith's understanding of how tariffs work seems soft. His assertion that as a consequence of the increases in import prices due to elevated tariffs domestic producers can choose to raise prices or enhance their share of the domestic market assumes that there is no serious domestic competition - which is nonsense - and that foreign firms might not begin doing business in France - as British textile makers did - to get around the tariffs. ${ }^{6}$ This understanding of economic depression coexisted with a continuing faith in Say's Law which asserts that production creates its own consumption. Fortunately, unlike economic agents maximizing utility, mentalités are not obliged to be rational constructs.
} 
state, also a bit fuzzy if analyzed with an eye to consistency, was that it should leave businessmen and growers alone to decide their own interests but also that it should intervene in civil society to protect National Production and a fragile new public order - made even more uncontrollable with the growing population of male workers armed with the right to vote. If looking back to the late nineteenth century, Smith finds French businessmen's polyvalent concerns about their workers in their factories and in society troubling, it may simply be an example of how modern presuppositions can cloud our readings of other times. Marx never claimed to have invented the phenomenon nor the idea of social conflict, nor even of, dare we write, "class". Nor did I. Must we think businessmen, workers, politicians, and intellectuals who spoke in the language of class conflict in the Third Republic did not know their own motivations?

This exchange has given me an opportunity to rethink the issues and arguments of not only my book but that of Smith. I saw it as an invitation to a new and, in view of the changing perspectives in other aspects of historical research, a long overdue Methodenstreit about how we frame discussions of the economic sphere. Although, on one level we agree on the most substantial issues about the events and long-term consequences of the first decades of the new French republic, Smith is not satisfied that we have enough evidence to make the assertions I have made. He suggests moreover, in his discussion of "French textiles", that, rather than tariff policy, technological innovations and the consequent alteration of the composition of the labor force in respect to skill and gender needs to be better attended to so that we may understand "labor-management relations in French textiles after 1892". Now there can be no doubting the earnestness of Smith's desire for more evidence, for the interrogation of the boxes of prefectorial reports in the archives, for many monographic studies of French firms to get at the questions he poses: he asked for these studies in his October 1989 review of my book in the American Historical Review, ${ }^{7}$ in his paper devoted to attacking my work at a French History conference in Santa Barbara, California in the November, 1990 (I am told), and for a third time in this article which the editors kindly sent me so that I might have an opportunity to reply.

I will defer to Michael Smith's greater enthusiasm for the kind of methodology exemplified in his present article and the positivist factual illusions it invents. And if he continues to do the kind of work he champions, we his readers must maintain, of course, the right to judge as to the adequacy of the number of case studies, the representativeness of the sample, and the interpretation of the motives he discovers in the business and government documents he will unearth. We would expect at the same time that he could

${ }^{7}$ American Historical Review, 94 (October 1989), pp. 1113-1114. 
supply some hard evidence for his technological innovation thesis, beyond the anecdotal tease he offers us in his article. In particular, he might consider whether in the French textile industry, by replacing unionized skilled male workers with fewer, less-well organized, less-skilled female workers, employers might not have gained a wider edge in the power relations on the job site. And would then this make the patrons (unsuspecting) dupes of Marxist class struggle notions - as in the case of their tariff advocacy - for all their rationalizing zeal ${ }^{8}$

My own conclusion from this exchange is that we historians have to look more closely at how we make economic arguments. What is indeed the role of rhetoric - persuasion, language - in formulating economic arguments? Can we infer motives from economic theory, or behavior, or from out-

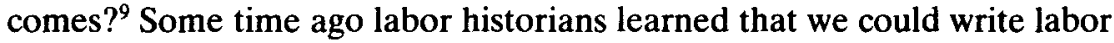
history neither from the numbers written on pay envelopes nor from party programs and resolutions, nor even from reading Capital. Moreover, a labor history that does not take account of employers - what I think of as tribal labor history - is a thing of the past.

Perhaps business history might need its E.P. Thompson or its Herbert Guttman, perhaps even a Clifford Geertz or a Pierre Bourdieu. The cast of characters which play Smith's story: personifications such as "mining and metallurgy", "pig iron and steel centers", "the French patronat"-economic men, to a man and precocious practitioners of modern economic theory to boot, as well as "skilled male spinners", "unskilled female machine tenders", both part of the "manpower [sic] needed per machine", and of course "the [sic] Marxists", lack the flesh and blood of the human beings confronting both great public questions and ones touching how they will live. It is rather the vision of society and economy of Dickens's Thomas Gradgrind of Coketown. This narrow kind of economic history might be better understood as a particularly unrewarding and wearying example of the literary genre of allegory than as an element in a serious social science discussion sensitive to the complexities of the world. Both Dickens and Zola were masters at representing the inanimate and the mechanical with human qualities and humans turned into administrative categories and machines. But rather than mystifying their readers, these outraged moral-

${ }^{8}$ Barbara Weinstein's forthcoming study of Brazilian industrialists' rationalizing efforts from the 1920 s to the 1960 s reassesses the widespread conviction found in the scholarship on the importance of the role of class conflict in the movement.

${ }^{9}$ Arjo Klamer suggests as a topic of interest for economists today "not to know how we, from an Archimedean position, can design rational criteria of truthfulness; it is instead to comprehend how economists [I would add here, and businessmen speaking on public policy, HL] actually argue and how their arguments work". Arjo Klamer, "As if Economists and their Subjects were Rational", in John S. Nelson, Allan Megill, Donald N. McCloskey (eds), The Rhetoric of the Human Sciences: Language and Argument in Scholarship and Public Affairs (Madison, WI, 1987), pp.163-183; quote on p. 163. 
ists used allegory to unveil the upside-down nature of nineteenth-century capitalist values.

How the discourse of economics functions in academic theory, in policy proposals, even in the firm, as we have seen, needs to be better understood. There is already an interest in the culture of firms in American business studies; more work on the culture of the worlds of business would be quite profitable for scholarship. Sources will still be important but we should get more from them than Smith's agenda for contracting archival silicosis. I invite Michael Smith to concern himself with these aspects of business history instead of recycling unexamined ideas to re-enact old ideological combats. 